\title{
A Qualitative Study of Barriers and Facilitators to Adherence to Secondary Prevention Medications Among French Patients Suffering from Stroke and Transient Ischemic Attack
}

This article was published in the following Dove Press journal:

Patient Preference and Adherence

\author{
Marie Viprey $\mathbb{( D}^{1,2}$ \\ Maïlys Gouillet ${ }^{3}$ \\ Costanza Puppo $\mathbb{D}^{3}$ \\ Anne Termoz ${ }^{1,2}$ \\ Claire Della Vecchia ${ }^{2,3}$ \\ Laurent Derex ${ }^{2,4}$ \\ Julie Haesebaert ${ }^{1,2}$ \\ Anne-Marie Schott (iD) ${ }^{1,2}$ \\ Marie Préau (D) ${ }^{3}$ \\ 'Public Health Department, Hospices \\ Civils de Lyon, Lyon, France; ${ }^{2}$ HESPER EA \\ 7425 , University of Lyon, University \\ Claude Bernard Lyon I, Lyon, France; \\ ${ }^{3}$ GRePS, Lyon 2 University, Lyon, France; \\ ${ }^{4}$ Comprehensive Stroke Center, Pierre \\ Wertheimer Hospital, Hospices Civils de \\ Lyon, Bron, France
}

\begin{abstract}
Purpose: Secondary prevention medications (SPM) reduce the risk of ischemic stroke (IS) and transient ischemic attack (TIA) recurrence. However, approximately one-third of patients are estimated to be non-adherent. This qualitative study aimed to explore barriers and facilitators to adherence to SPM after IS or TIA.

Patients and Methods: Thirty-six face-to-face semi-structured interviews were conducted with 14 TIA patients and 22 IS patients who self-administered their treatment 12 months after IS/TIA. A thematic analysis was performed.

Results: Major facilitators to good adherence to SPM were the fear of stroke recurrence and the high level of trust in the prescribing physician. Barriers included a perceived lack and/or inappropriate timing of information about SPM, practical difficulties of taking some SPM (eg, inadequate packaging) and of implementing routines into their daily life.

Conclusion: Information on SPM is inadequate in terms of quantity and timing both during the acute IS/TIA period and over the long term. Providing more tailor-made information at an opportune moment, in particular by promoting discussion with their general practitioner (GP) throughout the course of illness and recovery, is essential to ensure that patients are not left alone in the decision-making process regarding adherence to SPM.
\end{abstract}

Keywords: medication adherence, stroke, transient ischemic attack, qualitative study

\section{Introduction}

The risk of stroke recurrence is estimated at $13 \%$ in the first year and at $30 \%$ within 5 years. ${ }^{1}$ After a transient ischemic attack (TIA), the risk of stroke is estimated at $9 \%$ within 7 days and at $12 \%$ within 30 days. $^{2}$ The implementation of secondary prevention medications (SPM), sometimes combined with dietary and lifestyle recommendations, reduces the risk of recurrence following an ischemic stroke $(\mathrm{IS})^{3,4}$ or a TIA. ${ }^{5,6}$ Many studies have shown the importance of good adherence to these treatments to ensure their effectiveness. ${ }^{7-10}$ However, in a recent metaanalysis of 63 studies, overall medication adherence and persistence rates of patients with stroke were estimated, respectively, at only 64.1\% (95\% CI: $57.4-$ $70.8 \%$ ) and $72.2 \%$ (95\% CI: $69.1-75.3 \%) .{ }^{11}$

A good understanding of the determinants of adherence is fundamental to develop appropriate and effective actions to improve it. Most of the studies that have explored these determinants have examined pathology and treatment-specific factors. ${ }^{12}$ However,
Hospices Civils de Lyon, Pôle de Santé Publique, Bâtiment A, 6ème étage, 162 , Avenue Lacassagne, Lyon 69003, France Tel +33472 II 5302

Email marie.viprey@chu-lyon.fr 
factors related to the healthcare system, patient care trajectory, patient perception of their illness, as well as to their beliefs about treatment, should not be overlooked. In order to understand the psychosocial determinants of adherence to treatment in people's daily lives, the use of inductive qualitative methods is necessary. This approach makes it possible to consider treatments not only as medical objects but as social objects, ${ }^{13}$ and to understand the meaning that patients give to their behaviors regarding adherence or non-adherence. ${ }^{14}$

The few qualitative studies to date examining the determinants of adherence to SPM have only focused on patients with stroke. ${ }^{15-17}$ Accordingly, the objective of this study was to explore, using a qualitative approach, the barriers and facilitators to adherence to SPM among patients with IS or TIA who self-manage their treatment. Within the context of a mixedmethods approach, results from this qualitative study will help interpret results from the quantitative component.

\section{Materials and Methods Design and Participants}

Face-to-face semi-structured interviews were conducted with acute IS or TIA patients using an interview guide. The study implemented the Consolidated Criteria for Reporting Qualitative Research (COREQ) checklist. ${ }^{18}$ Study patients were participants of the Rhône County prospective population-based STROKE69 cohort. $^{19}$ Twelve months after their IS/ TIA, during a scheduled follow-up telephone interview with a clinical research associate, patients who self-administered their treatment and had a mRankin score $<2$, were solicited to participate in a semi-structured interview. Patients who were unable to communicate without the help of a caregiver were excluded. Those who agreed to participate were subsequently contacted by a social science researcher (MG) who explained the context of the interview and its characteristics.

\section{Interview Procedure}

Two exploratory interview guides, one for IS patients, the other for TIA patients, were created from existing literature, ${ }^{20-24}$ then tested in six exploratory interviews conducted by MG and adapted based on these interviews. Subsequently MG conducted face-to-face semistructured interviews using the final interview guides (Table 1) at 12 months after IS/TIA. Each interview started with a general question about the patient's experiences when IS or TIA occurred, followed by questions targeting six related themes: 1) the course and management of the acute phase and the experience of the
Table I Semi-Structured Interview Guide

\begin{tabular}{|c|c|}
\hline Themes & Sub-Themes \\
\hline Diagnosis announcement & $\begin{array}{l}\text { The experience of the diagnosis } \\
\text { announcement } \\
\text { [If the respondent has not yet } \\
\text { mentioned the word "TIA": Have you } \\
\text { ever heard of the term "TIA"?] }\end{array}$ \\
\hline Medical follow-up & $\begin{array}{l}\text { Relationship with health professionals } \\
\text { encountered in the context of stroke/ } \\
\text { TIA } \\
\text { Relationship with the general } \\
\text { practitioner }\end{array}$ \\
\hline Relationship with Health & $\begin{array}{l}\text { Self-assessment of their state of health } \\
\text { Behavioral changes and importance } \\
\text { given to health following stroke/TIA } \\
\text { Representations of the disease in } \\
\text { general }\end{array}$ \\
\hline Risk perception & $\begin{array}{l}\text { Perception of the causes of stroke/TIA } \\
\text { Perception of the risk factors for } \\
\text { recurrence } \\
\text { Behaviors to avoid recurrence }\end{array}$ \\
\hline Treatment & $\begin{array}{l}\text { Treatment description } \\
\text { Treatment adherence } \\
\text { Understanding of how treatment } \\
\text { works } \\
\text { Communication with physician about } \\
\text { treatment } \\
\text { Side-effects } \\
\text { Access to information about } \\
\text { treatment } \\
\text { Non-adherence to treatment }\end{array}$ \\
\hline $\begin{array}{l}\text { Representations of stroke } \\
\text { and changes in daily life }\end{array}$ & $\begin{array}{l}\text { Representation of stroke/TIA } \\
\text { Impact of stroke/TIA on daily life } \\
\text { Changes in quality of life following } \\
\text { stroke/TIA }\end{array}$ \\
\hline
\end{tabular}

Abbreviation: TIA, transient ischemic attack.

diagnosis announcement, 2) their medical follow-up, 3) their relationship with their health, 4) their perception of the causes and risk factors of IS/TIA, 5) their relationship with treatment, and 6) their representations of IS/ TIA and its impact on daily lives.

The interview location was chosen by the participants. Most were interviewed at home. A small number were interviewed at the research team's premises.

\section{Data Analysis}

All interviews were audio recorded, anonymized and fully transcribed. A thematic content analysis ${ }^{25}$ was performed. 
The first step consisted in skimming all 36 interviews, in order to get thoroughly familiarized with the content. The second step comprised a vertical analysis where discourse excerpts regarding adherence, its determinants and associated issues were identified. The third and final stage comprised a horizontal analysis based on the continuous thematization approach, whereby the thematic tree was constructed simultaneously with the identification of the themes which the units of discourse (identified during the vertical analysis) could be attached to. ${ }^{26}$ The sample was considered sufficient when data saturation was achieved (ie, no new theme emerged from an additional interview).

\section{Regulatory Proceeding and Ethics}

This study was approved by the ethics committee of Tours (France) and the National Commission on data protection (CNIL), and was registered in ClinicalTrials.gov NCT03153020. All participants provided oral informed consent, and that this study was conducted in accordance with the Declaration of Helsinki.

\section{Results}

\section{Population}

Fifty-one people agreed to be contacted by the researcher. Thirteen eventually did not participate in the study, for various reasons including unreachability, conflicting schedules, withdrawal, or impaired hearing. Two of the 38 interviews conducted were not included in the analysis because one was carried out with a non-autonomous person, and the other with a person no longer being prescribed treatment.

The 36 interviews included were conducted with 14 TIA and 22 IS patients. Interview lasted between 32 and 93 minutes. The sample comprised 16 women (mean age 70.2 years, standard deviation 16.3) and 20 men (mean age 70.5 years, standard deviation 15.5) (Table 2).

\section{Thematic Analysis}

Two main themes emerged from the analysis of the interviews. The first regarded barriers and concerns related to drug use, and included four sub-themes: i) lack of information and understanding about the disease; (ii) difficulties related to the practical management of medicines; iii) side effects; iv) the healing function of treatments. The second theme concerned facilitators and strategies for taking medicines and included three sub-themes: i) the trustful relationship with their doctor; ii) adapting medicine intake to their daily life routine; iii) the preventive function of the treatment. These themes and subthemes are discussed in greater detail below.

\section{Barriers and Concerns Related to Medicine Use Lack of Information and Understanding About the Disease}

Although most of the participants were able to name the condition they were given medicine for, less than half could explain how their treatments worked (eg, "thins the blood", "prevents clotting"). Most patients strongly regretted a perceived lack of information from doctors. They identified three barriers hindering good communication by their physicians: a lack of consultation time, technical jargon, and their own (ie, patients') cognitive failure to understand the information given to them in the acute phase. In the following quotes, IS/TIA represent the stroke type, M/F stand for male/female, and the number indicates the patient identification number.

'No. I didn't ask him, but he didn't tell me. Oh doctors ... they're not like those we had in the past who explained everything to us, what we had, explained the medicine to us, what it would do. [...] they don't have the time any more" (TIA F1)

"They try to explain to me [what a stroke is], but it's hard to explain to people who aren't in the trade. And then, it's difficult to explain because, they use terms like ... which aren't familiar to us." (TIA F3)

“I didn't know it was a stroke until I woke up in ... I knew after [...] But I was still out of it so I didn't understand anything ..." (IS M11)

\section{Difficulties Related to the Practical Management of Medicines}

Several factors could interfere with medication management. One was the change in routine, which could lead to the timing of intake changing or even to no intake.

\footnotetext{
"It's true that when you've, for example, guests at home, you think more about taking care of the guests, you don't necessarily care about the pills.” (IS M7)

"And then, if I've been partying and I get up late, I don't take them. [...] Because I don't even think about them! If I don't wake up every day at the same time, I'm ... I'm a little lost." (TIA M5)
}

Certain physical characteristics of medications represented additional difficulties for some participants, as for certain 
Table 2 Patients' Characteristics

\begin{tabular}{|c|c|c|c|c|c|c|c|c|c|c|}
\hline $\begin{array}{l}\text { Patient } \\
\text { Identification } \\
\text { Number }^{\mathbf{a}}\end{array}$ & Sex & $\begin{array}{l}\text { Place of } \\
\text { Ist } \\
\text { Admission }\end{array}$ & $\begin{array}{l}\text { Hospitalized } \\
\text { PSC/CSC (N } \\
\text { of Days) }\end{array}$ & $\begin{array}{l}\text { Hospitalized } \\
\text { Rehabilitation } \\
\text { (N of Days) }\end{array}$ & $\begin{array}{l}\text { Age } \\
\text { (Years) }\end{array}$ & $\begin{array}{l}\text { mRS } 12 \\
\text { Months } \\
\text { After } \\
\text { IS/TIA }\end{array}$ & $\begin{array}{l}\text { Marital } \\
\text { Status }\end{array}$ & $\begin{array}{l}\text { Socio- } \\
\text { Professional } \\
\text { Category }\end{array}$ & $\begin{array}{l}\text { Highest Level } \\
\text { of Education }\end{array}$ & $\begin{array}{l}\text { Number of } \\
\text { Prescribed } \\
\text { Medications }\end{array}$ \\
\hline IS MI & M & ED & no & no & 82 & 1 & married & $\begin{array}{l}\text { retired } \\
\text { before stroke }\end{array}$ & $\begin{array}{l}\text { High school } \\
\text { diploma }\end{array}$ & 4 \\
\hline IS M8 & M & ED & no & no & 85 & 1 & widowed & $\begin{array}{l}\text { retired } \\
\text { before stroke }\end{array}$ & $\begin{array}{l}\text { Technical } \\
\text { school } \\
\text { certificate }\end{array}$ & 6 \\
\hline TIA MI & M & ED & yes (6) & no & 79 & 0 & married & $\begin{array}{l}\text { retired } \\
\text { before stroke }\end{array}$ & $\begin{array}{l}\text { Technical } \\
\text { school } \\
\text { certificate }\end{array}$ & 3 \\
\hline TIA M2 & M & ED & yes (4) & no & 77 & 0 & married & $\begin{array}{l}\text { retired } \\
\text { before stroke }\end{array}$ & $\begin{array}{l}\text { Technical } \\
\text { school } \\
\text { certificate }\end{array}$ & 3 \\
\hline TIA F8 & $\mathrm{F}$ & $\mathrm{PSC} / \mathrm{CSC}$ & yes (4) & no & 78 & 0 & married & $\begin{array}{l}\text { retired } \\
\text { before stroke }\end{array}$ & $\begin{array}{l}\text { Technical } \\
\text { school } \\
\text { certificate }\end{array}$ & 2 \\
\hline TIA FI & $\mathrm{F}$ & ED & yes (6) & no & 83 & I & married & $\begin{array}{l}\text { retired } \\
\text { before stroke }\end{array}$ & $\begin{array}{l}\text { Technical } \\
\text { school } \\
\text { certificate }\end{array}$ & 3 \\
\hline IS FI & $\mathrm{F}$ & $\mathrm{PSC} / \mathrm{CSC}$ & yes $(7)$ & yes (26) & 50 & I & married & $\begin{array}{l}\text { retired or on } \\
\text { sick leave } \\
\text { since stroke }\end{array}$ & $\begin{array}{l}\text { Technical } \\
\text { school } \\
\text { certificate }\end{array}$ & 2 \\
\hline IS M4 & $M$ & $\mathrm{PSC} / \mathrm{CSC}$ & yes $(16)$ & yes (MD) & 51 & 0 & married & $\begin{array}{l}\text { retired or on } \\
\text { sick leave } \\
\text { since stroke }\end{array}$ & $\begin{array}{l}\text { Technical } \\
\text { school } \\
\text { certificate }\end{array}$ & 3 \\
\hline TIA F2 & $\mathrm{F}$ & $\mathrm{PSC} / \mathrm{CSC}$ & yes (3) & no & 38 & 0 & married & $\begin{array}{l}\text { active } \\
\text { employment }\end{array}$ & $\begin{array}{l}\text { Postgraduate } \\
\text { degree }\end{array}$ & 2 \\
\hline IS M2 & $M$ & $\mathrm{PSC} / \mathrm{CSC}$ & yes (4) & no & 78 & I & widowed & $\begin{array}{l}\text { retired } \\
\text { before stroke }\end{array}$ & $\begin{array}{l}\text { High school } \\
\text { diploma }\end{array}$ & 7 \\
\hline IS M5 & $M$ & $\mathrm{PSC} / \mathrm{CSC}$ & yes (4) & no & 68 & 0 & divorced & $\begin{array}{l}\text { retired or on } \\
\text { sick leave } \\
\text { since stroke }\end{array}$ & $\begin{array}{l}\text { Postgraduate } \\
\text { degree }\end{array}$ & 1 \\
\hline IS M3 & M & $\mathrm{PSC} / \mathrm{CSC}$ & yes $(8)$ & no & 54 & 0 & married & $\begin{array}{l}\text { active } \\
\text { employment }\end{array}$ & No diploma & 9 \\
\hline IS F2 & $F$ & $\mathrm{PSC} / \mathrm{CSC}$ & yes (6) & no & 53 & 1 & single & $\begin{array}{l}\text { active } \\
\text { employment }\end{array}$ & $\begin{array}{l}\text { Technical } \\
\text { school } \\
\text { certificate }\end{array}$ & 2 \\
\hline IS M7 & $M$ & $\mathrm{PSC} / \mathrm{CSC}$ & yes (8) & no & 71 & 0 & single & $\begin{array}{l}\text { retired } \\
\text { before stroke }\end{array}$ & $\begin{array}{l}\text { Technical } \\
\text { school } \\
\text { certificate }\end{array}$ & 3 \\
\hline IS M9 & M & ED & no & no & 92 & I & married & $\begin{array}{l}\text { retired } \\
\text { before stroke }\end{array}$ & $\begin{array}{l}\text { High school } \\
\text { diploma }\end{array}$ & 5 \\
\hline
\end{tabular}

(Continued) 
Table 2 (Continued).

\begin{tabular}{|c|c|c|c|c|c|c|c|c|c|c|}
\hline $\begin{array}{l}\text { Patient } \\
\text { Identification } \\
\text { Number }^{\mathbf{a}}\end{array}$ & Sex & $\begin{array}{l}\text { Place of } \\
\text { Ist } \\
\text { Admission }\end{array}$ & $\begin{array}{l}\text { Hospitalized } \\
\text { PSC/CSC (N } \\
\text { of Days) }\end{array}$ & $\begin{array}{l}\text { Hospitalized } \\
\text { Rehabilitation } \\
\text { (N of Days) }\end{array}$ & $\begin{array}{l}\text { Age } \\
\text { (Years) }\end{array}$ & $\begin{array}{l}\text { mRS I2 } \\
\text { Months } \\
\text { After } \\
\text { IS/TIA }\end{array}$ & $\begin{array}{l}\text { Marital } \\
\text { Status }\end{array}$ & $\begin{array}{l}\text { Socio- } \\
\text { Professional } \\
\text { Category }\end{array}$ & $\begin{array}{l}\text { Highest Level } \\
\text { of Education }\end{array}$ & $\begin{array}{l}\text { Number of } \\
\text { Prescribed } \\
\text { Medications }\end{array}$ \\
\hline TIA F5 & $\mathrm{F}$ & ED & no & no & 67 & 0 & married & $\begin{array}{l}\text { retired } \\
\text { before stroke }\end{array}$ & $\begin{array}{l}\text { High school } \\
\text { diploma }\end{array}$ & 2 \\
\hline TIA M5 & M & ED & no & no & 52 & 0 & married & $\begin{array}{l}\text { active } \\
\text { employment }\end{array}$ & $\begin{array}{l}\text { Technical } \\
\text { school } \\
\text { certificate }\end{array}$ & 2 \\
\hline TIA M3 & M & ED & no & no & 77 & 0 & married & $\begin{array}{l}\text { retired } \\
\text { before stroke }\end{array}$ & No diploma & 8 \\
\hline IS M6 & M & ED & yes (2I) & no & 66 & 1 & married & $\begin{array}{l}\text { retired } \\
\text { before stroke }\end{array}$ & $\begin{array}{l}\text { Postgraduate } \\
\text { degree }\end{array}$ & 7 \\
\hline IS MIO & M & ED & no & yes (13) & 97 & 0 & married & $\begin{array}{l}\text { retired } \\
\text { before stroke }\end{array}$ & $\begin{array}{l}\text { Technical } \\
\text { school } \\
\text { certificate }\end{array}$ & \\
\hline TIA M4 & M & ED & no & no & 75 & 0 & married & $\begin{array}{l}\text { retired } \\
\text { before stroke }\end{array}$ & $\begin{array}{l}\text { Undergraduate } \\
\text { degree }\end{array}$ & 7 \\
\hline IS MI2 & M & ED & no & no & 90 & 0 & married & $\begin{array}{l}\text { retired } \\
\text { before stroke }\end{array}$ & $\begin{array}{l}\text { Technical } \\
\text { school } \\
\text { certificate }\end{array}$ & I \\
\hline TIA F7 & $\mathrm{F}$ & ED & no & no & 48 & 0 & married & $\begin{array}{l}\text { active } \\
\text { employment }\end{array}$ & $\begin{array}{l}\text { High school } \\
\text { diploma }\end{array}$ & I \\
\hline IS MI4 & M & ED & yes $(6)$ & no & 86 & 0 & married & $\begin{array}{l}\text { retired } \\
\text { before stroke }\end{array}$ & $\begin{array}{l}\text { Technical } \\
\text { school } \\
\text { certificate }\end{array}$ & 5 \\
\hline IS F3 & $\mathrm{F}$ & ED & no & no & 63 & 0 & married & $\begin{array}{l}\text { retired } \\
\text { before stroke }\end{array}$ & $\begin{array}{l}\text { Technical } \\
\text { school } \\
\text { certificate }\end{array}$ & 5 \\
\hline IS F5 & $\mathrm{F}$ & ED & yes (3) & no & 85 & 0 & widowed & $\begin{array}{l}\text { retired } \\
\text { before stroke }\end{array}$ & MD & 4 \\
\hline TIA M6 & $M$ & ED & yes (16) & no & 80 & 0 & divorced & $\begin{array}{l}\text { retired } \\
\text { before stroke }\end{array}$ & $\begin{array}{l}\text { Technical } \\
\text { school } \\
\text { certificate }\end{array}$ & 8 \\
\hline IS F7 & $\mathrm{F}$ & ED & yes (3) & no & 79 & 1 & widowed & $\begin{array}{l}\text { retired } \\
\text { before stroke }\end{array}$ & $\begin{array}{l}\text { Undergraduate } \\
\text { degree }\end{array}$ & 3 \\
\hline IS F6 & $\mathrm{F}$ & $\mathrm{PSC} / \mathrm{CSC}$ & yes (9) & no & 74 & 1 & married & $\begin{array}{l}\text { retired } \\
\text { before stroke }\end{array}$ & $\begin{array}{l}\text { High school } \\
\text { diploma }\end{array}$ & 3 \\
\hline IS MII & $M$ & $\mathrm{PSC} / \mathrm{CSC}$ & yes (13) & no & 68 & 0 & divorced & $\begin{array}{l}\text { retired } \\
\text { before stroke }\end{array}$ & $\begin{array}{l}\text { Postgraduate } \\
\text { degree }\end{array}$ & 6 \\
\hline IS MI3 & $M$ & $\mathrm{PSC} / \mathrm{CSC}$ & yes (I2) & no & 41 & 0 & married & $\begin{array}{l}\text { active } \\
\text { employment }\end{array}$ & $\begin{array}{l}\text { High school } \\
\text { diploma }\end{array}$ & 2 \\
\hline
\end{tabular}

(Continued) 
Table 2 (Continued).

\begin{tabular}{|l|l|l|l|l|l|l|l|l|l|l|}
\hline $\begin{array}{l}\text { Patient } \\
\text { Identification } \\
\text { Number }\end{array}$ & Sex & $\begin{array}{l}\text { Place of } \\
\text { Ist } \\
\text { Admission }\end{array}$ & $\begin{array}{l}\text { Hospitalized } \\
\text { PSC/CSC (N } \\
\text { of Days) }\end{array}$ & $\begin{array}{l}\text { Hospitalized } \\
\text { Rehabilitation } \\
\text { (N of Days) }\end{array}$ & $\begin{array}{l}\text { Age } \\
\text { (Years) }\end{array}$ & $\begin{array}{l}\text { mRS I2 } \\
\text { Months } \\
\text { After } \\
\text { IS/TIA }\end{array}$ & $\begin{array}{l}\text { Marital } \\
\text { Status }\end{array}$ & $\begin{array}{l}\text { Socio- } \\
\text { Professional } \\
\text { Category }\end{array}$ & $\begin{array}{l}\text { Highest Level } \\
\text { of Education }\end{array}$ & $\begin{array}{l}\text { Number of } \\
\text { Prescribed } \\
\text { Medications }\end{array}$ \\
\hline IS F4 & F & PSC/CSC & yes (I5) & no & 49 & 0 & married & $\begin{array}{l}\text { retired or on } \\
\text { sick leave } \\
\text { since stroke }\end{array}$ & $\begin{array}{l}\text { High school } \\
\text { diploma }\end{array}$ & 2 \\
\hline TIA F6 & F & PSC/CSC & yes (8) & no & 88 & I & widowed & $\begin{array}{l}\text { retired } \\
\text { before stroke }\end{array}$ & $\begin{array}{l}\text { Technical } \\
\text { school } \\
\text { certificate }\end{array}$ \\
\hline IS F8 & F & PSC/CSC & yes (I) & no & 67 & 0 & divorced & $\begin{array}{l}\text { retired } \\
\text { before stroke }\end{array}$ & $\begin{array}{l}\text { Technical } \\
\text { school } \\
\text { certificate }\end{array}$ \\
\hline TIA F4 & F & ED & no & no & 84 & 0 & married & $\begin{array}{l}\text { retired } \\
\text { before stroke }\end{array}$ & $\begin{array}{l}\text { Technical } \\
\text { school } \\
\text { certificate }\end{array}$ \\
\hline TIA F3 & F & ED & no & no & 94 & 0 & widowed & $\begin{array}{l}6 \\
\text { retired } \\
\text { before stroke }\end{array}$ & MD \\
\hline
\end{tabular}

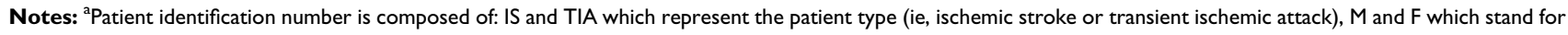
male and female, and a number which indicates the patient identification number.

Abbreviations: CSC, comprehensive stroke center; ED, emergency department; F, female; IS, ischemic stroke; M, male; MD, missing data; PSC, primary stroke center; TIA, transient ischemic attack.

tablets, which were difficult to take when fine motor skills were affected.

“There are two, which I don't like [...] One is very small, which I get back by sweeping [the floor]. The second is a capsule. I'm not able to pinch them properly. Often ... whoops, there it goes on the floor." (TIA M6)

This was also the case for acetylsalicylic acid in sachets, which were considered more difficult to take.

"It's the little powder you dilute in water, in the restaurant you don't do it, [... I I [can] see myself [in that situation] . . . There isn't always a free glass next to you [...], I need to ask for one and ... people look at you. Maybe." (TIA F5)

"It complicates taking medication, because it's a sachet, [...] you can't put it in the pillbox, you have to tear it, to put in a glass, with a bit of water and all that, and it's a bigger pain to take than all other medicines." (IS M8)

The latter patient declared he was no longer taking it, and justified this by the fact that the dose of acetylsalicylic acid was very small, and that he had got by without it for three months after his stroke, before it was first prescribed to him. In fact, in some clinical situations, the antiaggregant may be prescribed only a few months after the event.
In addition to medication management, sometimes the management of medical appointments could also prove to be a hindrance, as one of the participants indicated:

"I forget to go to the doctor to have the prescription renewed. I should have gone over a week ago.” (TIA M5)

Finally, most participants who reported changing how they took or stopping one of their medications said they had not talked about it to their doctor, or at least not at first.

"I did it without talking to him about it, and then when I realized that it was working out for me, that I, that I wasn't having any more lapses or ... and despite all, no more vertigo, I spoke to him about it." (TIA M2)

“No, I haven't seen him since. [...] You're [directed to the interviewer] not going to tell him, eh? [No no, it's not my role] No, because ... I told you ... the truth, so ... it's got to stay ... between us." (IS M8)

\section{Side Effects}

The issue of side effects influenced patients' representations of their medications. For example, gastric pain for those taking acetylsalicylic acid forced some participants 
to take an additional drug to mitigate these effects, or even stopped them from taking their medication.

"Anything to do with aspirin, for me that's a problem, because I've a hiatal hernia and [...] I get terrible heartburn. And aspirin is a factor that ... that does that. That's why I didn't ... I didn't continue very long, because it was uncomfortable." (TIA M1)

Some participants reported bleeding from the gums or nose and increased menstrual bleeding, which were regarded as disabling. Diuretics were also blamed by one participant, who stated that he rarely took them because of their excessive impact on daily life.

"There's one of the two diuretics that I take practically never take because ... it so ... disrupts my life, having the urge to urinate every ... every half-hour and that's ... you really don't live well. And so, you have to stay at home." (IS M8)

For certain participants medications had a negative impact on the body and were perceived to damage it just as much as to heal it.

\footnotetext{
"Yes, for a start the side effects, then there's the chemical molecules, [...] we have enough chemistry in the body, so ... that's one more, no, I ... I don't take it willingly, no. Nobody does, eh.” (TIA F5)

"I say to myself that I'm taking care of myself, but at the same time I say to myself that I'm losing out in terms of life expectancy." (IS M3)
}

\section{The Healing Function of Treatments}

Finally, some patients perceived medication as an element which attested to the presence of the disease. Its absence meant the disappearance of the disease, its cure.

"For me it was ... it was an indicator. The less I took the healthier I was, like." (IS M11)

Not being on treatment therefore corresponded, for some patients, to not being sick anymore.

"And, the doctor, he already stopped, last year ... I think two [pills]. I was relieved. To tell me that there were two less. I see it as something of an ... improvement" (TIA M6)

"These statins, first of all, I have two colleagues who are nurses, [...] they told me 'Listen I., it's a bit controversial, the effects, you know ...' '. So, already, as regards that, I wasn't very comfortable with this medication. Especially as I didn't have cholesterol. If I still had cholesterol, [at least] you'd be treating something concrete" (TIA F7)

Indeed, as the latter citation shows, some patients questioned the notion of preventive treatment. For them, the risk of side effects outweighed the benefit from taking this treatment, and therefore they perceived the function of medication more as curative than preventive.

Similarly, minimizing or casting doubt on their diagnosis of TIA led some participants to question taking medication.

"If I was really sure that it's .... that it's really that ... because there's a bit of doubt, I tell myself that I'm taking it for ... maybe for nothing, you know." (TIA M5)

Indeed, the majority of participants perceived their IS/TIA as "an accident, not really a disease" (TIA M2). These participants experienced the event as a one-off, objectified by the absence of severe sequelae, and distinguished their IS/TIA from a "classic" stroke, the latter being perceived as potentially lethal or causing greater handicap and loss of autonomy, something which was feared, in some cases, more than death itself.

"[An illness] ... you live it ... it accompanies you every day, it's there, it's present. For me, the TIA is finished ... it's behind me. There's nothing, there aren't any after-effects. Stroke, those who have after-effects have them. It's daily, they live with them." (TIA F7)

"I'm not bad, huh. I am a particular case." (TIA F5)

The fact that IS/TIA was not always identified as a disease by patients, had consequences on the credibility of medication and therefore on adherence.

\section{Facilitators and Strategies for Taking Medicines}

\section{The Trustful Relationship with Their Doctor}

Most participants perceived their medication as a necessity, even an obligation, objectified by its medical prescription.

"It sucks [to have to take them] (laughs). If he told me to take them, it's because .... it's important." (IS F2)

"I ... obeyed what I was prescribed." (TIA M4)

Trust in the attending physician knowledge was a very important facilitator for taking medication.

"He, my doctor, I trust him ... blindly. So if he tells me to take something, I take it." (IS F6) 
"No, but do you realize the studies they have to do? So, from the moment he said it ... a doctor, the medical profession is going to say, [...] he said 'take that', it's because they know it." (IS F7)

\section{Adapting Medicine Intake to Their Daily Life Routine} Most participants agreed that their treatment was not difficult to take, mainly because it was part of a new routine or part of a routine already in place for another non-IS/TIA treatment.

"You see, there are things that we do, systematically every day. We get up, we shave, [...] for me, in addition, there's taking medication." (IS M8)

"When I wake up. I don't worry about it. In any case, I don't forget it, it's every morning. Between $8 \mathrm{am}$ and 10am (laughs)." (IS F4)

Participants put strategies into place to sustain this routine: the use of pillboxes and alarms, places for storing medications, spatial and temporal organization, that became facilitators for adherence.

"I took a packet [of pills] and left it at work." (IS F2)

"I put them beside my bowl; that way I don't worry about forgetting them." (IS F5)

"I'm careful about ... about positioning the medication so that when I take it, I know I've taken it ..." (IS M11)

\section{The Preventive Function of the Treatment}

The fact that treatment was perceived to be mild was sometimes seen as an advantage and facilitated acceptance, particularly among those with reservations about allopathic medicine.

"I find it's a mild treatment, because [name of medication] isn't a strong medicine." (IS M2)

“And it's true that if he only gives me a little pill, it's mild all the same. Then, when you think about it you say ... 'Yeah, actually, it's not a big deal'." (IS F6)

Most participants were conscious of the potential consequences of a stroke. They felt they had been lucky and that a possible future stroke would be closer to what they perceived to be a "classic" stroke. They considered the IS/TIA they had had as an "alert" (TIA M1), "a warning" (TIA F6).
"Ah that, if I have a stroke again, I think that will be it [i.e., I'll die].” (IS M1)

"I feel like it's my body that spoke, that said 'Stop your bullshit! I'm going to give you a nice warning shot. [...] you won't have any after effects, but listen here ... this time. Because, the next time, you mightn't be so lucky'." (IS F4)

“There's always a little apprehension, ... because it can happen at any second, I need to be aware of the phenomenon, that it can happen anywhere, anytime. [...] They couldn't explain to me why I had a stroke. There was no answer. [...] you live with a sword of Damocles over your head ..." (IS M7)

This feeling of fear was stronger among participants in care in primary and comprehensive stroke centers or rehabilitation centers who had seen other people with much more serious sequelae.

"It's my obsessive fear, and I tell myself if I were to have another ... a TIA or a stroke ... Like, I've seen people, eh, who ... When I was in the neurology ward, there was this gentleman $[\ldots]$ he couldn't talk anymore, he couldn't [...] that's what ... I tell myself, I've come off pretty well, up to now." (TIA M3)

Accordingly, the fear of recurrence was a strong motivation for medication adherence for some participants. Taking medication was seen as a reassuring act which helped reduce the risks:

"I'm convinced of one thing [...], it's that if I stopped, well, I'd have new strokes.” (IS M6)

'It doesn't bother me to take it, and at a push I'd say, taking it reassures me. There you go, I tell myself that it reduces the risks and I don't want another [TIA] [...], it's really security for me." (TIA F2)

\section{Discussion}

This qualitative study highlighted a set of barriers and facilitators to adherence to SPM in IS/TIA patients who self-manage their treatment.

First, patients complained they had not received, or were not fit to receive information to help them understand their stroke/TIA and prescribed medications during their hospitalization in the acute phase. Stroke/TIA occurs suddenly and affects patients' cognitive capacity at the acute phase. ${ }^{27}$ Moreover, length of hospital stay is being increasingly reduced and patients often leave hospital with a poor 
knowledge and understanding of the disease and its treatments. In our study, even after the acute phase, general practitioners (GP) did not explain or discuss how medications functioned or the difficulties managing them although providing information throughout treatment is of utmost importance. ${ }^{16}$ Study patients were rather passive, their doctor-patient relationship being based essentially on the acceptance of doctor's scientific authority and knowledge. They often did not dear talking about adherence problems to the point that some voluntarily stopped or modified their treatments without telling their doctor. This may also be explained by their lack of knowledge leading to a lack of self-confidence, which in turn translated into diminished empowerment.

In the present study, the fear of recurrence, which participants often predict would be more serious than their first IS/TIA, seemed to be a powerful facilitator of medication adherence. This seems at odds with a review showing that fear was not a facilitator of change in health behaviors in primary prevention. ${ }^{28}$ However it is consistent with other studies on secondary prevention for patients who already experienced the event and some consequences of the disease. ${ }^{15}$

Our study confirmed that stroke has a particular identity status and was not identified by patients as a chronic disease, despite long-term treatment. ${ }^{29,30}$ The strictly preventionbased aim of SPM (therefore having no impact on the symptoms felt) may contribute to the feeling of identity. On the one hand, perception of stroke/TIA as a sudden, one-off occurrence and not a chronic disease may minimize people perceiving themselves to be sick, but on the other hand, it fuels the fear of an unforeseen sudden risk. Treatment adherence may therefore be seen as the only way to control this risk. Whether patients considered medication role as healing or preventive seemed to impact their perception. The first considered taking medications as potentially dangerous and a sign of their illness while the last were reassured by properly taking their medication.

The approach taken to daily medication management was also a determinant of adherence, especially when participants could set up a routine and daily habits, a result commonly found in the literature. ${ }^{15-17}$ More specifically, we identified practical elements impeding selfmanagement of medication in daily life and leading to non-adherence behaviors (eg, sachets difficult to open and not fitting in the pillbox, or very small pills). Nonserious yet uncomfortable side effects in daily life were also a factor of non-adherence, particularly bleeding (antiplatelets or anticoagulants) and polyuria (diuretics).

Using semi-structured interviews enabled participants to set their own orientation to their discourse and go beyond researchers' preconceptions, leading to a greater understanding of the issues specific to patient experience with adherence to SPM. While previous qualitative studies focused on stroke survivors often helped by their caregiver regarding the management of their treatments, ${ }^{15-17}$ our study focused on stroke survivors and TIA patients who self-managed their treatment, as this population is probably more at risk of non-adherence.

\section{Practice Implications}

This study provides valuable information that can be applied to daily care of IS/TIA survivors who selfmanage their medical treatment. At the acute phase, patient information should be very simple and provided both in oral and written formats to explain what has happened, why the treatment was prescribed, and how it works. This information could be shared with their GP who should also be trained to provide tailor-made information at opportune moments, to adopt an open and nonjudgmental attitude towards difficulties in medication adherence, and to pay more attention to patients' representation, health literacy, and environment to help them include their treatment intake into their daily routine. GP should be able to talk about the possible recurrence in the case of ischemic strokes, as this is the main reason why treatments are prescribed, and explain appropriate actions to take in this case since efficient treatments exist for the acute phase. Such information may help patients increase their sense of control to help them include their treatment intake into their daily routine. This approach could ensure that patients co-construct their representations of the disease and its treatment in collaboration with their GP, the latter providing appropriate information given at the right time. This would avoid patients developing inaccurate representations on their own. This would also improve patients' literacy and empowerment and help them to better interact with healthcare providers, notably by enabling them to ask questions and express their doubts and their difficulties to professionals.

\section{Conclusion}

Our results highlight that patient information SPM is inadequate in terms of quantity and timing both during the acute IS/TIA period and over the long term. In the 
acute IS/TIA period, patients are not capable of fully understanding the information about SPM. Providing more tailor-made information at opportune moments, in particular by promoting discussion with their GP throughout the course of illness and recovery, is essential to ensure that patients are not left alone in the decision-making process regarding adherence to SPM.

\section{Data Sharing Statement}

The datasets used and/or analyzed during the current study are available from the corresponding author on reasonable request.

\section{Acknowledgments}

We thank Amine Chakir, Héla Kerd, Ouazna Tassa for their participation in making telephone calls to patients, and Jude Sweeney for the translation and copyediting of this manuscript English version. We also thank Serkan Cakmak, Sylvie Meyran, Bruno Ducreux, Christelle Pidoux, Marc Du Besset, Thomas Bony, Pierre-Yves Gueugniaud, Marion Douplat, Veronique Potinet, Xavier Jacob, Alain Sigal, Karim Tazarourte, Christophe Lablanche, Regis Melaine, Norbert Nighoghossian for the inclusion of patients in STROKE69 cohort.

\section{Funding}

This work was supported by public funding from the Programme de recherche sur la performance du système des soins (PREPS 16-0592) and performed within the framework of RHU MARVELOUS (ANR-16-RHUS-0009) UCBL, as part of the program "Investissements d'Avenir" operated by the French National Research Agency (ANR).

\section{Disclosure}

The authors report no possible conflicts of interest in this work.

\section{References}

1. Burn J, Dennis M, Bamford J, Sandercock P, Wade D, Warlow C. Long-term risk of recurrent stroke after a first-ever stroke. The Oxfordshire community stroke project. Stroke. 1994;25(2):333-337. doi:10.1161/01.STR.25.2.333

2. Lovett JK, Dennis MS, Sandercock PAG, Bamford J, Warlow CP, Rothwell PM. Very early risk of stroke after a first transient ischemic attack. Stroke. 2003;34(8):e138-140. doi:10.1161/01.STR.000008 0935.01264 .91

3. Hackam DG, Spence JD. Combining multiple approaches for the secondary prevention of vascular events after stroke: a quantitative modeling study. Stroke. 2007;38(6):1881-1885. doi:10.1161/STROKEAHA. 106.475525
4. Park J-H, Ovbiagele B. Optimal combination treatment and vascular outcomes in recent ischemic stroke patients by premorbid risk level. J Neurol Sci. 2015;355(1-2):90-93. doi:10.1016/j.jns.2015.05.028

5. Rothwell PM, Giles MF, Chandratheva A, et al. Effect of urgent treatment of transient ischaemic attack and minor stroke on early recurrent stroke (EXPRESS study): a prospective population-based sequential comparison. Lancet. 2007;370(9596):1432-1442. doi:10.1016/S0140-6736(07)61448-2

6. Rothwell PM, Algra A, Amarenco P. Medical treatment in acute and long-term secondary prevention after transient ischaemic attack and ischaemic stroke. Lancet. 2011;377(9778):1681-1692. doi:10.1016/ S0140-6736(11)60516-3

7. Burke JP, Sander S, Shah H, Zarotsky V, Henk H. Impact of persistence with antiplatelet therapy on recurrent ischemic stroke and predictors of nonpersistence among ischemic stroke survivors. Curr Med Res Opin. 2010;26(5):1023-1030. doi:10.1185/0300799100 3670563

8. Perreault S, Yu AYX, Côté R, Dragomir A, White-Guay B, Dumas S. Adherence to antihypertensive agents after ischemic stroke and risk of cardiovascular outcomes. Neurology. 2012;79(20):2037-2043. doi:10.1212/WNL.0b013e3182749e56

9. Cummings DM, Letter AJ, Howard G, et al. Medication adherence and stroke/TIA risk in treated hypertensives: results from the REGARDS study. $J$ Am Soc Hypertens. 2013;7(5):363-369. doi:10.1016/j.jash.2013.05.002

10. Xu J, Zhao X, Wang Y, et al. Impact of a better persistence with antihypertensive agents on ischemic stroke outcomes for secondary prevention. PLoS One. 2013;8(6):e65233. doi:10.1371/journal. pone. 0065233

11. Zhang J, Gong Y, Zhao Y, Jiang N, Wang J, Yin X. Post-stroke medication adherence and persistence rates: a meta-analysis of observational studies. J Neurol. 2019. doi:10.1007/s00415-019-09660-y

12. Al AlShaikh S, Quinn T, Dunn W, Walters M, Dawson J. Predictive factors of non-adherence to secondary preventative medication after stroke or transient ischaemic attack: a systematic review and meta-analyses. Eur Stroke J. 2016;1(2):65-75. doi:10.1177/23969 87316647187

13. Conrad P. The meaning of medications: another look at compliance. Soc Sci Med. 1985;20(1):29-37. doi:10.1016/0277-9536(85)90308-9

14. Fainzang S. [The Doctor-Patient Relationship: Information and Lies]. Paris: Presses universitaires de France; 2006. French

15. Bauler S, Jacquin-Courtois S, Haesebaert J, et al. Barriers and facilitators for medication adherence in stroke patients: a qualitative study conducted in French neurological rehabilitation units. Eur Neurol. 2014;72(5-6):262-270. doi:10.1159/000362718

16. Souter C, Kinnear A, Kinnear M, Mead G. Optimisation of secondary prevention of stroke: a qualitative study of stroke patients' beliefs, concerns and difficulties with their medicines. Int $J$ Pharm Pract. 2014;22(6):424-432. doi:10.1111/ijpp.12104

17. Jamison J, Graffy J, Mullis R, Mant J, Sutton S. Barriers to medication adherence for the secondary prevention of stroke: a qualitative interview study in primary care. Br J Gen Pract. 2016;66(649):e568576. doi:10.3399/bjgp16X685609

18. Tong A, Sainsbury P, Craig J. Consolidated criteria for reporting qualitative research (COREQ): a 32-item checklist for interviews and focus groups. Int J Qual Health Care. 2007;19(6):349-357. doi:10.1093/intqhe/mzm042

19. Xue Y, Haesebaert J, Derex L, et al. Choice of initial brain imaging in patients with suspected acute stroke: STROKE69, a population-based study. Cerebrovasc Dis. 2020:1-9. doi:10.1159/000505960.

20. Heiby EM, Carlson JG. The health compliance model. J Compliance Health Care. 1986;1(2):135-152.

21. Becker MH. Patient adherence to prescribed therapies. Med Care. 1985;23(5):539-555. doi:10.1097/00005650-198505000-00014

22. Pender NJ. A conceptual model for preventive health behavior. Nurs Outlook. 1975;23(6):385-390. 
23. Walsh JM, McPhee SJ. A systems model of clinical preventive care: an analysis of factors influencing patient and physician. Health Educ Q. 1992;19(2):157-175. doi:10.1177/109019819201900202

24. Sabaté E, Organization WH. Adherence to Long-Term Therapies: Evidence for Action. World Health Organization; 2003.

25. Bardin L. [The Content Analysis]. Paris: Presses universitaires de France; 2007.French

26. Paillé P, Mucchielli A. [Qualitative Analysis in the Humanities and Social Sciences]. Paris: A. Colin; 2013.French

27. Della Vecchia C, Préau M, Carpentier C, et al. Illness beliefs and emotional responses in mildly disabled stroke survivors: a qualitative study. PLoS One. 2019;14(10):e0223681. doi:10.1371/journal.pone.0223681
28. Ruiter RAC, Kessels LTE, Peters G-JY, Kok G. Sixty years of fear appeal research: current state of the evidence. Int J Psychol. 2014;49 (2):63-70. doi:10.1002/ijop.12042

29. Moscovici S. [Psychoanalysis, Its Image and Audience]. 3rd ed. Paris: Presses universitaires de France; 1961.French

30. Moscovici S. [The Scandal of Social Thought: Unpublished Texts on Social Representations Collected and Prefaced by Nikos Kalampalikis]. Editions de l'Ecole des hautes études en science sociale; 2013.French

\section{Publish your work in this journal}

Patient Preference and Adherence is an international, peer-reviewed, open access journal that focuses on the growing importance of patient preference and adherence throughout the therapeutic continuum. Patient satisfaction, acceptability, quality of life, compliance, persistence and their role in developing new therapeutic modalities and compounds to optimize clinical outcomes for existing disease states are major areas of interest for the journal. This journal has been accepted for indexing on PubMed Central. The manuscript management system is completely online and includes a very quick and fair peer-review system, which is all easy to use. Visit http:// www.dovepress.com/testimonials.php to read real quotes from published authors. 